\title{
A GRAMÁTICA DAAÇÃO DE TRABALHADORES EM COOPERATIVAS DE PRODUÇÃO NO SUL DO BRASIL
}

\author{
Ricardo Mayer*
}

\begin{abstract}
Este trabalho busca investigar a gramática da ação de trabalhadores em cooperativas de produção constituídas no bojo dos processos de reestruturação econômica ocorridos no Brasil a partir dos anos 90 do século XX. Com base em uma sociologia da experiência, decompomos a lógica da ação dos trabalhadores engajados na formação de duas cooperativas de produção, onde procuramos investigar: $a$ ) as relações de solidariedade, $b$ ) a lógica da ação estratégica em cada coletivo de trabalhadores, e $c$ ) os processos de subjetivação expressos na construção identitária dos trabalhadores das cooperativas investigadas. Investigando duas cooperativas de produção na região metropolitana de Porto Alegre, verificou-se um processo de subjetivação marcado por uma atitude ambivalente entre o compromisso com o projeto de construção da cooperativa e uma postura pautada por certo pragmatismo tipificado por um campo de possíveis, restrito no tocante às alternativas de reinserção social.

PALAVRAS-CHAVE: gramática da ação, solidariedade, cooperativas de produção, autogestão, sociologia da experiência.
\end{abstract}

\section{INTRODUÇÃO}

A chamada crise da sociedade salarial, ${ }^{1}$ que se evidencia de forma nítida na reestruturação econômica e nos processos de reorganização e flexibilização das condições de uso da força de trabalho que acometeram a economia mundial, mormente na última década do século XX, ${ }^{2}$ tem engendrado estratégias defensivas por parte dos sindicatos e da classe trabalhadora no sentido da preservação de suas condições materiais de subsistência. Tais estratégias têm se configurado na constituição de cooperativas como alternativa para assegurar o trabalho e a geração de renda para o contingente de trabalhadores engolfados pelos processos de reor-

* Doutor em sociologia. Professor do Departamento de Ciências Sociais da Universidade Federal de Santa Maria - UFSM. Avenida Roraima, n. ${ }^{\circ} 1000$ - Campus Universitário, Prédio $74 \mathrm{CCSH}-2 .^{\circ}$ andar, sala 2205. Cep: 97105-900, Camobi - Santa Maria - RS - Brasil r.mayer@pq.cnpq.br ${ }^{1}$ Ver Castel (1998) e Gorz (2003; 2004).

${ }^{2}$ Deixando um saldo marcado por inúmeras falências e concordatas de empresas situadas nos setores menos dinâmicos da economia, pela precarização das condições de emprego e pelo surgimento de uma população economicamente sem condições de "empregabilidade" segundo os novos parâmetros de produtividade e competitividade da economia mundializada. Ver Pochmann (2001). ganização das bases de acumulação capitalista.

Por seu turno, a formação de cooperativas de trabalhadores também concorre para produzir controvérsias teóricas ${ }^{3}$ sobre as possibilidades concretas de as cooperativas se constituírem num avanço efetivo em termos da democratização do trabalho e autonomia dos trabalhadores a partir da eliminação das antigas hierarquias que caracterizavam a gestão das empresas em questão e da criação de novas solidariedades operárias. Assim, o trabalho autogestionário também é percebido como uma contrafação democrática, como mais um item da panóplia patronal para flexibilizar e reduzir os custos da mão de obra. ${ }^{4}$ Não obstante, tal discussão acaba sendo pouco frutífera do ponto de vista da compreensão das relações sociais tramadas nessas formas de organização social do trabalho. In-

3 Tal controvérsia remonta aos debates levados a cabo no seio do movimento socialista no século XIX sobre as potencialidades emancipatórias do trabalho autogestionário no âmbito das cooperativas de produção. O paradigma do cooperativismo contemporâneo se constituiu a partir da experiência das cooperativas de trabalhadores que surgiram na Inglaterra no ano de 1844 em Rochdale, nas proximidades de Manchester. Para mais detalhes dessa discussão, ver Santos; Rodríguez (2002). ${ }^{4}$ Ver Lima (1998; 2004). 
versamente, preferimos indagar sobre os padrões de sociabilidade configurados no âmbito das cooperativas de trabalhadores investigadas, ou seja, qual o campo de possíveis para uma efetiva experimentação e inovação social, tendo como perspectiva uma mudança nas relações de poder que caracterizam as empresas capitalistas tradicionais.

No que se segue, iremos enfocar duas cooperativas de produção procurando analisar a configuração da gramática da ação que se estabelece nessas empresas autogestionárias. ${ }^{5} \mathrm{Ou}$, de modo mais específico: iremos analisar suas lógicas da ação, consubstanciadas nas suas relações de solidariedade; na sua ação estratégica; e, por fim, os processos de subjetivação dos trabalhadores associados nessas cooperativas de produção.

\section{A CONFIGURAÇÃO DAS LÓGICAS DA AÇÃO}

Em grande medida, a ação social pode ser percebida a partir de um princípio de integração social traduzido em termos de interiorização do social. Da mesma forma, a identidade também é forjada no curso de processos de socialização primária que darão a medida da adesão subjetiva a expectativas sociais que são atualizadas constantemente nos processos de interação social. Tais experiências estão de tal forma amalgamadas subjeti-

${ }^{5}$ Foram realizadas 55 entrevistas semiestruturadas com trabalhadores de duas cooperativas de produção: a cooperativa A foi constituída no final de 2000 , a partir da falência da metalúrgica Vogg, e nela estão associados atualmente 152 trabalhadores. Situada na cidade de $\mathrm{Ca}-$ noas, na região metropolitana de Porto Alegre, a Cooperativa A atua no ramo metal-mecânico, produzindo bens de capital para as indústrias petrolífera, petroquímica, de papel e celulose, siderúrgica, química, de geração de energia elétrica e construção civil. Em 2007, o faturamento da Cooperativa A foi algo em torno de $\mathrm{R} \$ 16$ milhões de reais. Dentre os mais de 200 itens customizados que fabrica, destacam-se os de caldeiraria pesada, pontes rolantes, guinchos, estruturas metálicas, autoclaves, tubulações e comportas, etc. A cooperativa B possui atualmente um efetivo de 200 trabalhadores e foi fundada a partir da falência da antiga Companhia Geral de Indústrias. Localizada na cidade de Guaíba, na região metropolitana de Porto Alegre, dispõe de uma linha de produção que contempla, dentre outros produtos, uma gama de fogões a lenha e a gás, aquecedores de água e metais sanitários. Em julho de 2007, os trabalhadores associados à cooperativa B adquiriram as instalações da Companhia Geral de Indústrias com uma oferta em leilão público de R\$ 2.762.500, valor correspondente a $65 \%$ do ativo da massa falida, avaliada em R\$ 4.250.000. vamente, que chegam a configurar uma espécie de segunda "natureza". Assim, para tratar das relações sociais tramadas no âmbito de cooperativas de produção industrial constituídas na Região Metropolitana de Porto Alegre, no curso da última década, iremos nos valer da sociologia da experiência proposta por François Dubet (1996). Nesses termos, a análise da sociabilidade desdobrada nesses coletivos de trabalhadores que buscam implementar uma organização do trabalho autogestionária será decomposta num tríplice registro, qual seja, a integração social, a ação estratégica e a subjetivação e que culminam, por seu turno, em diferentes tipos de relação social e lógicas da ação. O recurso à noção de experiência de Dubet busca evitar algo como uma concepção de ação social na qual o sujeito seria mero suporte das estruturas sociais. A opção pela noção de experiência se revela adequada na medida em que não podemos reduzir a ação social à mera interiorização de papeis, tampouco à pura persecução de interesses individuais. Na configuração esquemática dessas três lógicas da ação, teríamos a primeira lógica da ação, constituída pelo pertencimento, pelo vínculo social percebido a partir de um princípio de integração social traduzido em termos de interiorização do social. Nesse registro de sociabilidade, prevalecerá a questão das formas de solidariedade que tornam possível algum tipo de integração social que poderá ser de natureza comunitária ou societária. ${ }^{6}$ É aqui que se pode conceber a coalescência dos vínculos sociais marcados por sociabilidades primárias ou secundárias, por relações sociais horizontais ou verticais, ou mesmo ainda por diferentes tipos de relações de solidariedade. ${ }^{7}$ Da mesma forma, as questões relativas aos possíveis déficits de integração social poderão ser tratadas como patologias sociais a partir da noção de anomia, pois, um sistema de relações sociais pode se decompor quando entra em crise, desorganizando-se e engendrando situações de marginalização, exclusão e invalidação social ${ }^{6}$ Ver Dubar (1997, p.87).

${ }^{7}$ A lógica da integração encontrará sua primeira formulação teórica na sociologia durkheimiana; ver também Dubet; Martuccelli (1999) 
as mais diversas. Para Dubet (1996), a integração social constituir-se-á numa das lógicas da ação a ser gerida pelos atores no âmbito de sua experiência social. Aqui, como em Thompson (1987, p.10), será através de sua experiência que o indivíduo irá se impregnar das tradições, hábitos, costumes, valores e moralidade referentes ao seu universo. Mas, o termo interiorização, talvez seja demasiado forte para dar conta do fato de que não se trata apenas de absorção, mas também de invenção e de um processo no qual são reelaborados os significados de valores culturais presentes na trama diária das relações sociais. ${ }^{8}$

A consistência desses vínculos sociais poderá ser percebida a partir de diferentes tipos de relações de solidariedade, as quais poderão ser caracterizadas pela preponderância de uma forma de solidariedade sobre as demais. Para efeito de nossa discussão, poderíamos considerar dois tipos de solidariedade, operando cada um mediante lógicas distintas: uma solidariedade funcional e uma solidariedade contratual. ${ }^{9}$ A solidariedade funcional é definida através do conceito durkheimiano de solidariedade orgânica: ou seja, as relações de solidariedade derivam da diferenciação e complementaridade de funções desempenhadas no interior de um grupo social integrado a partir da divisão social do trabalho. A solidariedade contratual está relacionada a um cálculo racional através do qual a associação se configura na estratégia mais adequada para a concretização de objetivos individuais e coletivos, o que torna possível a aliança, o acordo, o contrato coletivo. ${ }^{10}$

Mas as relações sociais não se resumem somente à questão da integração social. Na segunda lógica da ação, iremos nos deparar com o sistema político e com processos institucionais de legitimação política desencadeados entre o Estado

${ }^{8} \mathrm{O}$ modo pelo qual tal experiência é apropriada culturalmente pelos trabalhadores concorreria, conforme François Dubet, para configurar aquilo que já foi definido no âmbito da teoria marxista como consciência de classe, porém sem o peso de qualquer viés historicista, tal como se pode encontrar nas formulações clássicas desse conceito em Lukács (1974), por exemplo, quando opera com as noções de classe-em-si e classe-para-si.

${ }^{9}$ Aqui, as noções de solidariedade funcional e contratual remontam a Tönnies, Durkheim e Weber.

${ }^{10}$ Aqui nos baseamos em Bajoit (1992). e a sociedade civil. Pode-se falar, então, numa esfera política que compreende formas variadas de pressão, influência e participação política, através de associações, sindicatos ou partidos políticos, tendo em vista a disputa pela redistribuição de bens públicos, o reconhecimento de direitos sociais e (ou) culturais, ou mesmo a luta pelo poder político. Aqui, as questões relacionadas à preservação do status quo ou a demandas por reconhecimento social poderão deflagrar, por exemplo, conflitos e mobilizações políticas pela defesa ou reivindicação de direitos sociais, através da definição de uma ação estratégica ${ }^{11}$ com vistas à consecução dos objetivos políticos perseguidos pelas organizações em liça.

Dessa forma, de modo ilustrativo, podemos configurar a seguinte tipologia no que tange à racionalidade dos atores ante sua adesão a uma cooperativa de produção. Com efeito, a primeira opção que surge em relação a uma cooperativa pode ser definida como um compromisso, ${ }^{12}$ como um engajamento em relação ao projeto de formação das cooperativas. Trata-se de uma opção caracterizada pelo envolvimento ativo em relação aos valores e mesmo a um eventual projeto ideológico subjacente à constituição das cooperativas. Trata-se ainda de vínculos que, unindo os trabalhadores às cooperativas, forjam uma identidade e mesmo uma ligação emocional a esse projeto. De um modo geral, o compromisso firmado tacitamente decorre daqueles trabalhadores que, ao longo de sua trajetória profissional, tiveram algum tipo de participação sindical. Podemos incluir também nessa categoria

${ }^{11}$ A ação é estratégica quando é ponderada a partir de critérios de escolha racional e da observância do grau de influência sobre as ações de outros atores sociais. Nesse sentido, as relações sociais também podem ser percebidas a partir do modelo do mercado, porém não podem ser reduzidas a essa única dimensão de racionalidade. Ver Dubet (1996, p.126), Dubet; Martuccelli (1999, p. 83) e Habermas (1987, p.367).

12 Segundo Goffman (1991, p.148), a participação numa organização implica, de partida, compromisso e adesão. As categorias relativas a ação estratégica guardam alguma similaridade com as propostas por Albert Hirschman (1973). Entretanto, enquanto Hirschman reduz a teorização da ação à sua dimensão da racionalidade estratégica ou a uma moral do interesse, aqui se parte da premissa que isso implica apenas uma das lógicas que a ação social pode vir a assumir. Rejeitamos, portanto, os pressupostos utilitaristas presentes nas ciências sociais para dar conta da ação social. 
aqueles trabalhadores que, desde o primeiro momento, estiveram à frente das mobilizações que culminaram na criação das cooperativas. Há, por fim, aqueles trabalhadores cujo compromisso e participação na cooperativa envolvem ainda sua família, passando a assumir quase o caráter de uma herança a ser transmitida ao filho escolhido para ocupar seu lugar (Bajoit, 1992). Assim, um exemplo característico da postura em relação às cooperativas que presume um compromisso ativo pode ser visualizado na seguinte fala de um trabalhador:

No tempo que se trabalhava com patrão, você saía de casa sem um compromisso, não tava nem aí; e hoje você sai de casa com um compromisso, com responsabilidade. O trabalho aqui é mais artesanal, cada um faz o seu trabalho e não pode fazer outro que não vai saber fazer. Se o presidente conscientizar todos os sócios da responsabilidade que eles têm, o resultado vai ser melhor pra qualquer empresa não só pra cooperativa. Se houver um comprometimento de todos, você vai ver um ajudando o outro e isso a gente ainda não tem. Alguns já entenderam... O problema que sendo velho demais é ruim de botar na cabeça, e o novo é mais rebelde, não tá nem aí, então você tem que pegar um pessoal de fora pra dar um curso que aí eles aprendem (Associado, 54a. Cooperativa A).

A segunda possibilidade de ação estratégica em relação às cooperativas pode ser definida em termos de protesto. Aqui, temos a situação de quem aderiu e se comprometeu inicialmente com a formação da cooperativa, mas que, no entanto, demonstra uma postura crítica em relação aos rumos tomados posteriormente por ela, bem como pela forma como ela vem sendo gerida pela direção. Existe, portanto, certo descontentamentoem relaçãoaos dirigentes, e sua críticaé dirigida às opções, às escolhas assumidas e suas possíveis consequências em termos do futuro da própria cooperativa. A protestação pode questionar atéa própria legitimidade dos trabalhadores que ocupam os cargos de direção da cooperativa, buscando promover mudanças para que, dessa forma, ela volte a conciliar meios e fins segundo esse tipo de avaliação. Aquele que protesta não rompeu ainda com o projeto da cooperativa, mas busca, antes, redefinir seus rumos. De um modo geral, as posturas de protestação são marcadas pelo seguinte discurso:
A cooperativa surgiu de um projeto político muito bem articulado e que sensibilizou muitos setores da sociedade, pois isso aqui foi quase exemplar. E aí se articulou todo esse processo, e até começar a cooperativa, eu diria que foi quase um sucesso. A grande dificuldade da cooperativa foi daí pra frente, ou seja, ao invés de ter um projeto visando muito mais à viabilidade de um aspecto técnico e econômico, a cooperativa não saiu daquela fase anterior à sua abertura, ela continuou política, et cetera e tal, subestimando isso aí... Ao invés da obrigatoriedade de saltar de um momento político-social para um técnico-econômico com rapidez, inteligência e clarividência, nós não saímos; então, hoje se enfrentam muitos problemas por causa disso aí. Por exemplo, a maior dificuldade que nós temos aqui foi a elaboração de um planejamento financeiro de caráter técnico-econômico, ela não teve isso até agora. Porque isso possibilitaria um controle de alavancagem de recursos disponíveis e de produção. Tudo deveria ser alavancado pela viabilidade da cooperativa, porque esses programas de cultura, de recursos humanos, isso tudo acaba depois sendo de certa maneira resolvido com certa naturalidade... (Associado, 58a. - Cooperativa B)

A terceira possibilidade, presente desde o início, é diametralmente oposta à cooperação e ao compromisso e pode ser definida como uma estratégia unilateral de defecção, isto é, um abandono em relação ao projeto da cooperativa. Nesse caso, a adoção dessa alternativa teria implicado a saída e a recusa à participação na cooperativa. Mas, ante esta possibilidade extrema e considerando-se as alternativas concretas de reinserção social, existe ainda uma quarta possibilidade que se evidencia numa atitude de resignação. Trata-se de uma postura inversa à de protestação, pois, ao mesmo tempo em que traduz certa apatia em relação à cooperativa, procura tirar algum proveito da situação, extrair alguma vantagem antes de optar pela defecção. Nesse sentido, essa postura pode ser definida como certo pragmatismo, na medida em que o ator não adere e não se identifica mais com os objetivos da organização. Ele, antes, “explora o sistema”, furtando-se e subtraindo-se do comprometimento com as questões coletivas. Tal atitude se revela de forma explicita na seguinte fala:

Eu estou aqui, primeiro porque foi a única porta que me abriram. Tem três circunstancias que tu não consegue emprego: falta de experiência, que 
era meu caso, falta de escolaridade e se não for essa, é pela idade. Eu caí nessa pela experiência. Eu estou aqui não por obrigação, mas eu penso que aqui não é meu chão. Eu estou estudando, me preparando porque também vou enfrentar o que enfrentei aqui: falta de experiência. Então, quando estiver em certo semestre, tchau. É só pra pegar experiência (Associado, 28a. - Cooperativa $\mathrm{A}$ ).

Sem embargo, a racionalidade estratégica também está presente no registro da ação coletiva. Aqui, competem entre si, na explicação das ações coletivas, diversas abordagens teóricas. ${ }^{13}$ Não obstante, nos apoiaremos em Touraine (1973) para postular que o ator é formado essencialmente pelo conflito e pelo reconhecimento daquilo que está em jogo no conflito social. Assim, conjugando as categorias tourainianas de identidade, oposição e totalidade, poderemos ter, ideal-tipicamente, uma medida da reflexividade dos atores. Trata-se, antes, de uma análise combinatória a partir da qual poderemos nos deparar com um ator social desde sua mais acabada expressão, configurada num movimento social, quando, por exemplo, os três princípios estão presentes, o que, porém, pode corresponder também a uma visão demasiadamente idealizada do que viria a ser um movimento social, até a ação coletiva no seu estado mais incipiente. Não obstante, a correlação de tais princípios é ainda muito útil para a análise de outras configurações da ação coletiva em termos de projeto. Ou seja, a combinação de tais princípios entre sié capaz de esclarecer não somente os diferentes níveis de reflexividade e coordenação da ação coletiva, mas também pode definir os contornos assumidos pela lógica da subjetivação. Ao mesmo tempo, as patologias referidas à lógica da ação estratégica estarão relacionadas à obstrução da ação a partir do cerceamento do seu campo de possíveis, bem como as crises de legitimação da ação a partir da incoerência entre os fins e os meios empregados para persegui-los.

Mas os atores não se resumem apenas aos seus pertencimentos nem aos seus interesses. No

${ }^{13}$ Extrapola os limites da presente argumentação uma exposição das várias correntes teóricas que se debruçam sobre a análise da ação coletiva. Para tanto, remetemos o leitor a Daniel Cefaï (2007) ou ainda, Gohn (1997), especialmente os capítulos II e III. registro da subjetivação, eles podem se definir como sujeitos a partir da reelaboração das representações de si que lhes são propostas pelo social. Tal processo não resulta de uma representação ancorada numa predefinição ontológica de como deva se constituir o sujeito, mas, antes, dos processos de socialização e construção identitária no curso de suas trajetórias individuais confrontados com os conflitos e ante a alteridade de sua situação de classe. Aqui, reiteramos que os atores só são reconhecidos como tais na medida em que se constituem em termos de projeto, ou seja, controlando sua experiência vivida e tendo como perspectiva a possibilidade de sua transformação. Já as patologias que atingem os processos de subjetivação estão relacionadas, por seu turno, às formas de alienação que tolhem a capacidade de agir dos atores. A cisão entre concepção e execução, entre o trabalhador e sua obra, implica a reificação das relações sociais que se apresentam como forças e mecanismos incompreensíveis que se abatem sobre o sujeito como leis naturais. A alienação também é a perda de sentido, é o desencantamento do mundo corroído pela racionalidade instrumental, é a perda da possibilidade de compreender o mundo e a vida social como resultante da ação humana. No caso de nosso objeto de investigação, iremos encontrar a ação coletiva desenvolvida no segundo nível de projeto, ou seja, onde os elementos da tríade identidade, oposição e totalidade estarão correlacionados aos pares. Entretanto, não estamos aqui diante de uma de ação coletiva deflagrada por um supersujeito histórico, que busca estabelecer algum tipo de hegemonia a partir do controle das grandes orientações societárias (algo, aliás, mais adequado à narrativa épica do que à análise sociológica), mas, antes, de uma modalidade de ação coletiva encetada por organizações como as cooperativas de produção, cujo escopo máximo de intervenção será o sistema institucional e político. De um modo geral, a ação buscará, nesse aspecto, de um lado, o reconhecimento social e político, através da proposição e alteração de dispositivos legais que visam a desobstruir a organização dos trabalhadores em cooperativas, e, de outro, a afir- 
mação, através da definição de políticas públicas consubstanciadas na obtenção de, por exemplo, linhas de financiamento junto a organismos financeiros governamentais, ou em políticas de desenvolvimento nos termos de uma economia solidária. Mais especificamente, a ação desenvolvida pelas cooperativas de produção implica também um movimento político mais amplo, no qual os sindicatos revisam suas estratégias ante os processos de reestruturação econômica e estabelecem ações defensivas para evitar o desaparecimento de postos de trabalho com a simples liquidação judicial de empresas em situação falimentar. Voltaremos a essa questão mais adiante.

Nesse processo, os trabalhadores das cooperativas de produção são capazes de afirmar sua identidade, ou seja, têm consciência e orgulho daquilo que são, da mesma forma que sabem pelo que lutam e se mobilizam, configurando sua ação, desse modo, a partir de um princípio de oposição. Constituem, assim, movimentos de reivindicação cujo móbil principal é a preservação do trabalho ou, de um modo geral, uma luta pela preservação de sua dignidade como trabalhadores. ${ }^{14}$ É claro que, nesse processo de construção identitária, persistem muitas ambivalências caracterizadas pelo nível de comprometimento dos trabalhadores com o empreendimento, com a sua identificação com os valores que balizam a nova forma de regulação das relações sociais no âmbito da cooperativa e, por fim, com a ruptura de sua autoimagem como trabalhador assalariado e a constituição de uma nova representação de si como cooperado.

\section{ENTRE DUAS FORMAS DE SOLIDARIEDADE}

Como categoria sociológica o trabalho se configura, sociologicamente, como possibilidade de reconhecimento social e fonte de solidarieda-

14 Tal diagnóstico expressa antes um tipo ideal. Poderemos encontrar ainda, em muitas situações, apenas a conformação da identidade, ou seja, os trabalhadores são capazes de definir o que são, mas não contra quem ou contra o quê eles se batem e nem aquilo que é capaz de legitimar sua ação. O que os configuraria, então, apenas como grupos de pressão. de. Pode-se mesmo afirmar que a identificação de uma sociedade do trabalho soa quase como truísmo sociológico. Mas, há de serem consideradas aqui as solidariedades do universo fabril que estabelecem as condições mínimas de possibilidade para que os trabalhadores se convertam num ator coletivo, condição para a mobilização em torno dos processos de conquista de direitos trabalhistas. Elas implicam o reconhecimento social de um estatuto e mesmo de um tipo específico de cidadania social relativa ao mundo do trabalho. Ao mesmo tempo, o trabalho também é reconhecido como instância de produção coletiva, como resultado de uma práxis coletiva que transcende a particularidade dos trabalhos realizados por indivíduos concretos. Tal reconhecimento associa-se, por outro lado, à conceptualização do trabalho como trabalho abstrato, ou seja, como o reconhecimento da atividade laboral como trabalho em geral, independentemente das formas particulares que assume. Para além de sua conversão em mercadoria, a conceptualização do trabalho como trabalho abstrato também concorre para que ele surja como uma atividade pública coletiva, fazendo com que o trabalhador ocupe, através dos seus organismos de representação, o espaço público. Oreconhecimento, no âmbito das relações sociais de produção, também conforma identidades e produz as variantes de solidariedade resultantes da divisão social do trabalho. Tal categoria desempenha, dessa maneira, um papel central na organização da existência individual. Nesses termos, o trabalho pode implicar um certo tipo de coerção moral, um dever ser, uma relação social plena de obrigações recíprocas que terminam solidarizando os grupos sociais.

Entretanto, as relações assalariadas de trabalho engendram um vínculo social caracterizado pelo disciplinamento do trabalho fabril, a partir do alheamento dos trabalhadores em relação aos meios de produção. Dessa forma, o possível compromisso moral em relação ao trabalho, que deveria constituir-se num dever ser dos trabalhadores em cooperativas de produção recentemente formadas, parece conter certa dissonância moral, ou seja, o engajamento de alguns trabalhadores em relação 
à cooperativa parece guardar alguns resquícios que reportam sua ação ao passado do trabalho servil e disciplinado, que obedecia à lógica da utilidade econômica, a partir da qual adquiria seu significado. Tal é o sentido que podemos depreender na fala de uma trabalhadora das cooperativas investigadas:

Eu torno a te dizer que o pessoal tá um pouco perdido... Então, os que sabem mais vão passando pra outros, mas a intenção é que todos cresçam juntos. A cooperativa é muito boa porque tu tem um certo... Tu tem que ter consciência que tu tem um horário a cumprir como numa empresa normal, pois se você não vir vão precisar de você, tu vai fazer falta, não tem quem te substitua, então tu tem que ser o mais pontual possível... Ela meio que se mistura com uma empresa normal, só que tu tens mais livre acesso, digamos assim, que tu é um pouquinho dono, e como todo dono de negócio tem que tá sempre em cima. Então, eu adorei, acho muito interessante, eu já trabalhei em empresa privada e... Até trago um pouco da privada pra cá, porque antigamente tava um pouquinho bagunçado, mas tu tem mais... Tu não precisa estar todo tempo prestando conta, mas tu tem que ser consciente do que tu faz, porque, mais tarde, aquilo pode vir a te prejudicar e quem tá na tua volta, então assim fica mais fácil de você trabalhar (Associada, 36a. - Cooperativa B).

Com efeito, o senso de obrigação e uma moral do compromisso parecem diluir-se quando em confronto com a cultura de trabalhador assalariado interiorizada muitas vezes ao longo de uma trajetória profissional que alcança a aposentadoria de vários trabalhadores associados às cooperativas. O senso da hierarquia está fixado, gravado na história e na experiência de trabalhadores que encontram dificuldades no processo de readaptação à nova estrutura de relações surgida com a conversão da empresa em cooperativa. Ao mesmo tempo, o sentimento de desconfiança de alguns trabalhadores habituados a um tipo de sociabilidade caracterizado por uma reciprocidade negativa ${ }^{15} \mathrm{OS}$ impede de perceber a possibilidade de outro tipo de sociabilidade pautado por relações de reciprocidade não-regidas pela troca impessoal. Ou seja, numa situação marcada pela predominância de uma reciprocidade negativa, o indivíduo busca, de um

15 Trata-se de um comportamento que busca maximizar suas expectativas de ganho sem o dispêndio da devida contrapartida. Para mais detalhes, ver Sahlins (1977). lado, maximizar, incrementar suas expectativas de ganho, e, de outro, minimizar seus custos eventuais. Trata-se de uma forma impessoal de intercâmbio característica das relações de trabalho assalariadas, nas quais a prevalência do cálculo utilitário é capaz, no limite, de configurar uma moral calcada preponderantemente no interesse individual. Tal situação pode ser ilustrada na fala de um diretor da cooperativa A:

Então, tem limites, e as pessoas não aceitam os limites. Ainda tem pessoas que vivem no modelo antigo, de que o chefe é o chefe, fulano é o fulano e assim por diante, eu faço a minha; não pode ser assim. Então essa é uma diferença grande que tem que é a mudança de comportamento das pessoas, as pessoas têm que aceitar e entender o processo, não adianta. Eu aceitei tranquilo, mas sai dali não entendi nada, mas tu só entendeu, tu não aceitou o processo, tu não conseguiu assimilar a diferença que tem da antiga empresa pro atual modelo. Então, o atual modelo é bom, mas você tem que sair atrás, tem que buscar alternativas, tem que ter conhecimentos, tem que buscar; em primeiro lugar, a confiança do colega, do sócio, tu tem que ter confiança, tu tem que ter certeza e tem que ter garantia do negócio. Garantia do negócio é o grupo organizado. Então, hoje em dia é difícil organizar o grupo... Então, esse processo, ele é cruel; ele é lento e cruel porque você tem que tá toda hora mostrando pras pessoas de que você é honesto, de que você aderiu; $O$ cooperativado, ele tem que ser cooperativado internamente; no dia-a-dia nosso aqui, e lá fora. Lá fora, ele tem que falar conectado com nós aqui dentro, falar bem da Cooperativa, a família dele tem que tá ciente, tem que tá feliz também por ter conseguido se engajar nesse processo, porque o processo é rico; ele é muito rico. Num país onde tem esse desemprego enorme, você ter oportunidade de lutar pelo seu dia a dia, seu ganha-pão é privilégio hoje, hoje a gente pode dizer que nós estamos sendo privilegiados hoje com isso. Então o trabalhador, ele tem esse momento de reflexão de que tem momentos de que tá bom, tem momentos que já não tá legal. Quando não tá legal que já tão metendo a mão. Então esse é o grande desafio nosso; é o grande problema que nós achamos até hoje, a gente conseguiu; lá no meio da base mesmo a gente conseguiu identificar ele. Que as pessoas não confiam nas pessoas ainda, [...] nós estamos hoje com 95\% já equilibrado nesse processo aí de grau de confiança... (Presidente da Cooperativa A, 48a.)

Mas as relações de solidariedade se estabelecem e permanecem ao longo do tempo, juntamente com mecanismos de controle social que irão 
variar segundo a preponderância deste ou daquele vinculo de solidariedade. Assim, nas cooperativas investigadas, devido a suas características com respeito à forma de organização do trabalho, dos processos produtivos e das competências e qualificações requeridas, deparamo-nos com uma preponderância das relações de solidariedade de natureza funcional e contratual. Com efeito, nas cooperativas de produção, a trama dos vínculos sociais será assegurada primeiramente pela predominância das relações de solidariedade funcional, cujo controle normativo, exercido reciprocamente por todos trabalhadores da cooperativa, estará baseado tacitamente num compromisso moral em relação à produção e à organização do trabalho. A consciência das obrigações recíprocas entre os trabalhadores das cooperativas, que cimentam suas relações de solidariedade, confere também um novo sentido ao trabalho que decorre não somente da interdependência derivada das especializações e diferenciações funcionais, mas também do senso de um projeto comum, endossado pelos trabalhadores na sua adesão. Para alguns trabalhadores, a participação na cooperativa implicou uma ruptura com o alheamento em relação ao trabalho, que, por vezes, caracteriza a disposição atitudinal de trabalhadores assalariados em empresas privadas. Uma ruptura que poderia indicar o surgimento de uma nova "mentalidade", segundo a expressão de um entrevistado, ou ainda de uma nova disposição em relação ao trabalho, cujos contornos podem ser visualizados nas seguintes falas dos trabalhadores:

A visão de uma cooperativa e uma empresa privada, é que, na empresa privada, tu vai trabalhar, eu faço minhas oito horas, bato meu cartão, meu patrão que me manda, me paga. Se tiver serviço, eu faço, se não tiver, no fim do mês meu patrão tem que me dar meu salário. Só. Aqui, eu sou soldador, mas se não tiver solda pra mim, eu vou ajudar outro colega. Isso é cooperativa, união, nós temos que pegar junto, porque quanto mais rápido nós pegarmos e acabarmos o serviço bem feito e entregarmos pro cliente é ponto pra nós. E isso é a maior vontade da gente, todo mundo ter essa mentalidade. Apesar de uma minoria ainda ter aquela, são muito antigos, tem anos, mas a maioria já pensa diferente... O que é que acontecia antes? Se eu não terminava um serviço, o patrão era obrigado a me dar o salário do mês, mas na cooperativa não, nós temos que trabalhar junto porque a cooperativa é minha, se eu atrasar o serviço eu vou atrasar o meu salário e o de todos, porque tu é dono da cooperativa, tu tem que segurar também, não pode se escorar no fulano. Eu faço a minha parte e ele faz a parte dele e ambos são vencedores. (Associado, 42a. - Cooperativa A).

Ser uma cooperativa é que todo mundo tem que fazer o serviço pra poder ganhar, então a participação tem que ser desde a direção até o último empregado lá, que varre. Todos têm que participar e tem o direito igual de discutir; porque a gente discute e o que a gente discute aqui é em assembleia, qualquer coisa que tiver de errado; se reúne todo mundo e diz - Tem isso, isso e isso, o quê que vocês acham, quem é que vota contra, quem é que vota a favor. Então, as coisas são decididas tudo no grupo, apesar de ter um conselho de ética, de saúde, disso, daquilo, mas realmente quem decide mesmo é a assembleia geral. Então acho que devagarzinho a gente vai conseguindo... Cada um faz sua função, mas o problema é o seguinte; se eu tiver carregando uma peça que tá muito pesada tu tem que me ajudar também a carregar, porque a gente é dono tudo da mesma peça e quer ver aquela peça pronta, é assim que deve funcionar... (Associado, 53a. - Cooperativa A).

Entretanto, ao lado das obrigações e do engajamento em relação ao trabalho, características das relações de solidariedade funcional, encontramos também, no âmbito da lógica da integração e do pertencimento social, outro tipo de solidariedade, marcada, sobretudo, pelo contrato. Mais que um simples contrato, trata-se aqui de pactuar uma regra, de modo a instituir uma nova forma de regulação social entre os membros das cooperativas. Mas trata-se também de uma solidariedade de tipo contratual, produzida por um cálculo que pondera o campo de possíveis e os recursos disponíveis diante da necessidade de se efetuar uma escolha. Não obstante, tal asserção pode nos levar a confundir a racionalidade subjacente ao contrato com a racionalidade estratégica: pois, enquanto essa última pondera os interesses com o intuito de maximizar ganhos e minimizar perdas, a primeira invocará a regra para afirmar sua legitimidade e confirmação de sua validade. Da mesma forma, enquanto a última irá projetar o futuro a partir da permanência e estabilidade das regras, condição mesma para a definição do cálculo estratégico, a primeira se desdobrará como um processo de aprendizagem coletiva, 
prevendo mesmo a alteração das regras caso haja necessidade. Tanto numa quanto noutra forma de racionalidade, os atores irão perseguir seus interesses, submetendo-se às regras do jogo, porém a racionalidade estratégica será governada por um princípio de utilidade, enquanto a racionalidade contratual será governada por um princípio de regulação social. ${ }^{16}$ Nesse sentido, a legitimidade da solidariedade de tipo contratual pode ser sintetizada no seguinte depoimento de um trabalhador associado a uma das cooperativas:

Regras tem no estatuto e no regimento interno. Ali estão colocados os direitos e deveres de cada um, no estatuto, e tem o regimento, que é tipo um resumo do estatuto, que controla o funcionamento da cooperativa. Por exemplo, se o cara roubar ou fizer outra coisa, brigar ou chegar bêbado, qual medida que vai ser tomada. Tem o comitê disciplinar, que até hoje não foi usado... Não precisou ser usado... É, porque quando chegar no comitê disciplinar, é porque a coisa já descambou, porque se tem alguma coisa errada tu chega e conversa com o cara numa boa. Pisar na bola o cara pode pisar, qualquer um pode pisar. Mas, tem outros recursos... Pelo regimento tem advertência verbal primeiro, tem advertência por escrito, segundo. Depois tem o comitê disciplinar, terceiro. E depois tem a assembleia ainda pra julgar. Quer dizer, o cara não é afastado assim. Diferente da empresa. Na empresa, é: "Não vou com a cara daquele sujeito ali, tchau pra ti. Não quero saber. Passa no departamento". Do regimento, eu fiz parte da elaboração. Nós ficamos reunidos vários dias. Discutimos, acho que em 15 pessoas, que foram escolhidos pra ler, reler e ver se aprovava pra depois passar pela assembleia. Depois foi passado em assembleia, lidos todos os itens, pra ser aprovado. Tinha uma comissão pra ser aprovado primeiro, mas pra ser aprovado tinha que passar em assembleia. Mesma coisa com o estatuto, foi lido todo ele, parágrafo por parágrafo. Ninguém escreveu isso e deu. (Associado, 34a. - Cooperativa B).

No tocante ao processo de adesão à cooperativa, do ponto de vista dos valores, essa parece encontrar mais ressonância entre os trabalhadores mais jovens. Trata-se daqueles trabalhadores, cujas perspectivas de trabalho dependem em grande medida do êxito e continuidade do projeto da cooperativa, diferentemente, portanto, daqueles tra-

${ }^{16}$ Para maiores detalhes ver Reynaud (1997, p.29). balhadores cuja perspectiva imediata é a aposentadoria e o recebimento dos créditos trabalhistas devidos pela antiga empresa. Essa situação é caracterizada da seguinte forma pelo mesmo associado do último depoimento: "Muitos já foram embora, eram aposentados, não queriam mais trabalhar... E é onde nós tamos vencendo... Com os mais novos... E, todos que entram vão pra uma sala de treinamento, a gente explica o que é a cooperativa, o que tem que fazer..." (Associado, 42a. Cooperativa A).

Mas, a admissão na cooperativa implicará também a distribuição de bens sociais, e o primeiro bem, cuja distribuição será discutida e ponderada entre os trabalhadores associados, será a própria qualidade de membro da associação. Segundo Michael Walzer (1999, p. 46), a qualidade de membro se constitui num bem primário, cuja definição dos critérios de distribuição poderá repercutir sobre as outras decisões de cunho distributivo de uma associação. Assim, ser admitido como membro de alguma associação pressupõe, ao mesmo tempo, partilhar obrigações e compromissos morais em relação aos outros associados, implicando uma relação social a meio caminho entre uma reciprocidade generalizada e uma reciprocidade equilibrada. ${ }^{17}$ Sejamos mais claros: as relações de reciprocidade generalizada correspondem ao ápice da solidariedade. Definem um tipo de relação cuja contra-obrigação é retribuída somente se possível. Aqui, a moral do interesse, o cálculo utilitarista, segundo o qual, na relação "uma mão lava a outra e duas lavam o rosto" ${ }^{18}$ está recalcado pelo social, pois o reconhecimento das dívidas, de débitos, de favores, enfim, do auxílio mútuo, não podem ser reduzidos a um simples raciocínio contábil, de modo que, muitas vezes, a contra-obrigação imediata pode ser deixada de lado. No entanto, isso não significa que a contra-obrigação será simplesmente descartada, mas que a expectativa

${ }^{17}$ Ver Sahlins (1977).

${ }^{18}$ A simetria de compensações, independentemente de qualquer outro tipo de consideração no âmbito da relação social, caracterizaria uma moralidade de tipo préconvencional. Para maiores detalhes, ver Habermas (1989), especialmente o capítulo 4. 
de reciprocidade será projetada para o futuro, pois existe, entre os membros da cooperativa, uma obrigação difusa de reciprocidade que cauciona suas relações de solidariedade. Mas, se as relações que ensejam uma reciprocidade generalizada estão assentadas nas relações sociais prevalecentes, a completa unilateralidade da relação, que caracteriza esse tipo de reciprocidade, não será tolerada indefinidamente. É por isso que adquire sentido a existência de uma reciprocidade equilibrada, que corresponderá a certa isonomia no tocante às obrigações e contra-obrigações que tecem os fios das relações de solidariedade entre os membros das cooperativas. Ser membro da associação corresponde a uma situação de integração social que extrapola o mero vínculo contratual, ou seja, as solidariedades e reciprocidades que se estabelecem entre os membros transcendem a fria letra do contrato de adesão à cooperativa. Porém, sendo já associados, os trabalhadores só podem distribuir essa qualidade de membro aos que estão fora, para aqueles que são estranhos. A seleção de novos associados será realizada, então, conforme a concepção acerca do significado para a cooperativa que a qualidade de membro encerra, bem como do tipo de cooperativa que se quer formar. Nesse sentido, a qualidade de membro associado como um bem social a ser distribuído será fixada, de um lado, pelas necessidades atinentes ao próprio processo de trabalho, e, de outro, por requisitos e atributos que definem um perfil do membro da cooperativa. co de engajamento nas lutas e mobilizações que conduziram à formação da cooperativa numa conjuntura de desemprego estrutural. Dessa forma, os critérios distributivos não são intrínsecos a nenhum bem em si, mas, são operacionalizados tendo como parâmetro os próprios membros da cooperativa. Isso fica mais claro quando a definição de quem passará a fazer parte pressupõe, inicialmente, sua indicação por outro membro já associado, cujo critério de recomendação será perpassado primeiramente pelas relações primárias de solidariedade. No entanto, tal indicação deverá ainda se "enquadrar" no perfil requerido durante um período determinado.

\section{ENTRE O COMPROMISSO E O PRAGMATISMO}

Existe um consenso, na literatura recente ${ }^{19}$ da sociologia do trabalho dedicada ao estudo do movimento sindical, de que os processos de modernização produtiva de matriz pós-fordista, que se desdobraram ao longo dos últimos 25 anos, repercutiram fortemente sobre a capacidade de organização e mobilização do sindicalismo, seja como instituição, seja como movimento social. Um dos referentes empíricos da crise enfrentada pelo sindicalismo pode ser verificado no declínio dos índices de sindicalização, bem como da ação coletiva dos trabalhadores organizados. ${ }^{20} \mathrm{~A}$ leitura corrente desse fenômeno sinaliza que a prevalência de um regime de acumulação fordista, durante grande parte do século XX, teria favorecido a organização e expansão do movimento sindical, mormente a partir das formas de organizar o trabalho e o processo de produção pressupostos pelo fordismo como paradigma de desenvolvimento industrial. Tratar-se-ía de um contexto fabril favorável ao estabelecimento de uma cultura operário-

${ }^{19}$ Ver Ramalho (2000); Rodrigues (1999); Cardoso (1999); Lévesque, Murray \& Lequeux (1998); Lapointe (1998). ${ }^{20}$ Os índices de sindicalização declinaram durante a década de 80 nas principais economias ocidentais, à exceção da Suécia, do Canadá, da Itália e da antiga RFA. Ver Cardoso (1999, p.163); Rodrigues (1999, p.177). 
sindical capaz de forjar identidades coletivas, de estreitar solidariedades de classe, de compor um estilo de vida a partir da homogeneização das qualificações e condições de subsistência da maior parte da classe trabalhadora. Sindicatos fortes e representativos, com um formidável poder de barganha nas negociações coletivas com o patronato, caracterizaram o mundo do trabalho num tipo de sociedade cuja predominância de uma condição salarial definia os principais contornos do mercado de trabalho, pelo menos para o contingente da força de trabalho situado nos setores mais desenvolvidos das economias urbano-industriais.

Não obstante, tal cenário passou a sofrer profundas modificações a partir da reestruturação da base técnica de acumulação capitalista, com a implementação de novas formas de organizar o trabalho e os processos produtivos, marcadas, sobretudo, pela flexibilização das condições de utilização da mão de obra, principalmente nas grandes e médias empresas, que, de um modo geral, têm fornecido a base sobre a qual os sindicatos afirmam sua capacidade de representação e inserção no chão de fábrica. A introdução de novas tecnologias organizacionais, inspiradas nos pressupostos da produção em fluxo tenso, ${ }^{21}$ a promoção de programas de qualidade associados à reorganização das estruturas hierárquicas, cujo sentido mais geral busca implicar cognitivamente e moralmente os trabalhadores em relação à produção e a empresa, teriam concorrido para contornar uma situação que, segundo Aglietta (1979, p.98), se fazia presente no fordismo: a linha de montagem taylorista-fordista tinha a tendência de unir os trabalhadores contra a intensificação do trabalho determinada pela gerência. Não sobrava muito espaço, portanto, para que o capital fomentasse divisões internas no coletivo fabril, bem como posturas de caráter individualista por parte dos trabalhadores. As mudanças na organização do trabalho e no processo de produção que decorrem da

21 Tais como o modelo just-in-time/kan-ban, que gera uma rede de relações intrafabris onde todos trabalhadores acabam se tornando "fornecedores" e "clientes" uns dos outros, o que de resto engendra uma situação onde cada um monitora e controla a performance dos colegas (Humphrey, 1994, p.156). implementação dessas novas tecnologias irão engendrar uma situação na qual o controle, antes exercido pela gerência, passará a ser internalizado pelos próprios trabalhadores, gerando, neles, uma disposição atitudinal marcada pela a adesão aos "valores" da empresa e por uma postura onde a emulação se constituirá num aspecto marcante das condutas e comportamentos individuais. A colaboração dos trabalhadores, que passam a ser identificados como "colaboradores", estará assentada em mecanismos de barganha que a gerência utiliza para interpelá-los individualmente: trata-se, sobretudo, de um envolvimento estimulado, no qual o escalonamento do salário segundo o tempo de serviço e os bônus por produtividade configurar-seão em verdadeiras "moedas de troca" do engajamento de cada operário em relação à produção (Humphrey, 1994). Na periferia desse mercado de trabalho, a flexibilização das condições de uso da força de trabalho irá configurar-se através de sua precarização mediante, principalmente, a intensificação da subcontratação, do trabalho em domicílio, do ingresso massivo das mulheres no mercado de trabalho, bem como do crescimento do desemprego crônico. No limite, tais estratégias gerenciais irão erodir as solidariedades operárias que caracterizaram a classe trabalhadora nos áureos tempos do fordismo.

Entretanto, tal interpretação da crise do sindicalismo, a partir do esgotamento de um dado padrão de acumulação capitalista concebido pelo nome de fordismo, pode nos conduzir a uma visão errônea acerca desses processos, ao menos por duas razões. A primeira é de ordem ontológica: ao enfatizar a importância das macroestruturas socioeconômicas em processos que ainda estão em curso, sugere-se sua determinação estrutural e retira-se de cena a ação coletiva dos trabalhadores, convertendo-os em meros suportes ou, quando muito, em expectadores de um processo marcado pelo drama social da diminuição dos postos de trabalho; e a segunda é de ordem epistemológica: ao enfatizar a tese da fragmentação das lealdades e solidariedades da classe trabalhadora, parte-se de uma visão demasiado mitificada do seu passado, 
representado como uma época na qual os trabalhadores, perfilados em seus sindicatos, constituíam-se numa classe-para-si. Para além dessa visão idealizada, Hyman (1996) argumenta que as coisas nunca se passaram de forma tão linear, mas que os sindicatos, como organizações, carregam consigo uma grande variedade de aspirações, valores e concepções de mundo, de modo que tanto a probabilidade do conflito quanto a do consentimento não estão muito longe uma da outra. Para que a ação coletiva dos trabalhadores seja possível, é necessário, pelo menos, que a combinatória dos princípios de identidade, oposição e totalidade esteja presente. Assim, a construção de expressões de solidariedade mais efetivas sempre demandou uma operação de construção da identidade, por oposição às classes dominantes, bem como a consciência dos conflitos que balizavam as lutas de classe nas sociedades industriais. De outra parte, Hyman (1996) também argumenta que a noção de classe operária se constitui, antes, numa abstração do que numa descrição ou generalização sociológica, pois as classes trabalhadoras têm sido caracterizadas mais pela diferenciação e heterogeneidade, e sua possível unidade e coesão é mais algo excepcional do que um traço comum de sua conformação. Quando realizada, a precária unidade das classes trabalhadoras tem se forjado no conflito, da mesma forma que as relações de solidariedade entre os trabalhadores se afirmam mais consistentemente em situações de adversidade. A prevalência de uma representação mitificada das classes trabalhadoras nos impediria de perceber mais objetivamente a própria crise vivenciada pelo sindicalismo. ${ }^{22}$

Nesse sentido, um dos desafios propostos ao sindicalismo é configurado pelo processo de desassalariamento da força de trabalho, o que, aos poucos, vem drenando o contingente da classe trabalhadora, historicamente representado pelos sindicatos. ${ }^{23}$ É a constatação que esta estampada na

${ }^{22}$ Ver também Ramalho (2000).

${ }^{23}$ Segundo um dirigente do Sindicato dos Metalúrgicos de Canoas entrevistado, a base sindical sobre a qual o sindicato atuava, nas décadas de 70 e 80 , correspondia a algo em torno de 17 mil metalúrgicos. Atualmente, esse número reduziu-se para algo em torno de 9 mil trabalhadores. avaliação de um dirigente sindical:

Em 78, 79, nós tinha, na nossa base ,na média de 16 a 17 mil metalúrgicos. Só pra ti ter uma noção, hoje nós tamos com 9 mil. Nós tinha uma Maxion que tinha 5 mil trabalhador, fabricava 70, 80 trator por dia. Hoje ela tem 1200, 1300 e fabrica quase 200. Diminuiu mais de $50 \%$ da mão de obra. Tinha uma Auston que era a antiga Coenza que tinha 1700 trabalhador, hoje tá com 400. Maxiforja tinha 700, hoje tá com 280. Aí pega uma (LIAS) Metalúrgica que tinha, eu trabalhei 5 anos lá, que tinha mil e poucos funcionários, hoje tá com 200. Então esse processo foi violento aqui. É aquela história; não só a modernização das máquinas foram, as empresas foram evoluindo, algum tipo de terceirização também, isso tira muito... Fragmenta muito... Foi violento.. Agora, de 97 pra cá, ela tá mantendo um nível de 9 mil, um pouco mais, um pouco menos. Mas, nos anos 80, foi violento. 80 e 83 aqui foi... (Dirigente sindical, 50 a. - Sindicato dos Metalúrgicos de Canoas).

Contrapor-se a esse cenário pressupõe a elaboração de novas estratégias com o propósito de ampliação do sentido da solidariedade para além das fronteiras que a delimitavam no passado, de modo a reestruturar a agenda sindical para que os sindicatos possam não só organizar trabalhadores desempregados e trabalhadores associados junto a cooperativas, mas também representá-los politicamente. Mas a ampliação do escopo de atuação dos sindicatos, ao conjugar estratégias defensivas com uma linha de intervenção de caráter mais propositivo, pode estar representando um processo de transformação do sindicalismo. Ou seja, para Leôncio Martins Rodrigues (1999, p.207), se os sindicatos passarem a exercer funções que hoje são preenchidas por entidades que organizam segmentos populacionais não-assalariados - tais como cooperativas, movimentos sociais policlassistas, associações de bairro -, ou ainda ampliarem sua agenda política, passando a incluir temáticas como a defesa ecológica, estaremos ante uma situação na qual o próprio fundamento da representação sindical estaria sendo alterado. Tal mudança na direção de atuação dos sindicatos poderia ser percebida também como uma forma de declínio do sindicalismo segundo a sua conformação tradicional predominante nas sociedades ocidentais.

No entanto, a própria Central Única dos 
Trabalhadores (CUT), ${ }^{24}$ partindo de avaliações que ponderam as consequências das transformações no mundo do trabalho sobre o movimento sindical, tem buscado implementar novas estratégias de intervenção com o intuito de contemplar os trabalhadores associados às cooperativas de produção. Pois, segundo Magalhães \& Todeschini (2000), a configuração de uma nova estrutura no mercado de trabalho a partir dos processos de reestruturação econômica estaria criando perspectivas para o surgimento de novas experiências de geração de trabalho e renda no bojo das políticas de economia solidária. O que, entretanto, não deixa de propor questões desafiadoras para o próprio movimento sindical, dado que tais experiências de autogestão podem estar se ajustando a um mercado de trabalho dualizado, caracterizado por um núcleo privilegiado de trabalhadores assalariados que gozam de um leque de direitos sociais ao lado de um grupo de trabalhadores sem direitos, associados às cooperativas. É o que ocorre quando cooperativas são constituídas no âmbito de estratégias empresariais de subcontratação e terceirização, com a finalidade de redução dos custos do trabalho. Com efeito, a discussão em torno das questões suscitadas pelos processos de precarização e flexibilização das condições de uso da força de trabalho culminou com a adoção de uma estratégia de cunho defensivo por parte dos sindicatos, materializada na criação pela CUT, em 1999, de uma Agência de Desenvolvimento Solidário para sustentar a constituição de empreendimentos autogestionários através do assessoramento, apoio técnico e político na formação de cooperativas no âmbito de um projeto de uma economia solidária. Para os sindicatos, trata-se de apoiar a formação e a consolidação de um "cooperativismo autêntico", caracterizado pela participação igualitária de todos os trabalhadores associados às cooperativas nos processos de deliberação e gestão desses empreendimentos autogestionários. Neste aspecto, os sindicatos têm desempenhado um papel fundamental no que poderia ser tratado nos termos de

${ }^{24}$ Ver Magalhães; Todeschini (2000). uma luta pelo reconhecimento da dignidade e utilidade social de trabalhadores, cujos postos de trabalho simplesmente desapareciam não fosse a ação político-sindical no sentido da constituição das cooperativas. Mas a definição de tal política por parte dos sindicatos filiados a CUT não se procedeu sem que fosse objeto de questionamentos acerca da negociação de créditos trabalhistas quando da falência de uma empresa. Pode-se mesmo afirmar que a definição de uma estratégia sindical no qual a hipótese de se apoiar à constituição de uma cooperativa, ao invés da simples liquidação judicial de uma empresa, resultou de um estreitamento do campo de possíveis da ação sindical tradicional. ${ }^{25}$ É o que fica claro a partir do depoimento de um ex-membro da direção do Sindicato dos Metalúrgicos de Canoas e atual presidente de uma das cooperativas investigadas:

... movimento sindical hoje ele tem que apontar pra uma coisa, ele tá apontando já, porque nós perdemos uma grande oportunidade em Canoas; que a base é Nova Santa Rita também, da Bicicletas Ferrari. Em 94, nós tivemos o mesmo processo que passou a Vogg, e nós tava tudo pronto pra formar uma cooperativa, Bicicletas Ferrari, tudo pronto, só que o Sindicato muito dividido numa teoria, numa tese de que não podemos negociar os direitos dos trabalhadores e coisa e tal, já tava tudo pronto pra fazer uma cooperativa, inclusive o maquinário todo pra distribuir a área em lotes pros funcionários, 260 trabalhadores. Acabou nós perdendo tudo, porque nós não chegamos a um consenso. Que tinha um pouco do sindicato, da CUT a visão de que vamos deixar fechar, vamos discutir na falência os direitos dos trabalhadores e não existe isso. A empresa faliu, não existe mais direito dos trabalhador nenhum; acabou, isso aí é história. Então, o movimento sindical tem que apontar pra isso, ele tem que correr lá na frente, ele tem que já ter investimentos nesse tipo de modelo pra gente saber que decisão vamos tomar ali na frente. Então, acho que o sindicato tem que apontar pra isso, sindicalismo hoje tem que apontar; ou é melhor deixar falir ou é melhor recuperar a empresa com autogestão, uma nova forma e futuramente, comprar, que é o que nós queremos fazer aqui. (Presidente da Cooperativa A, 48a.).

Portanto, a opção de sustentar politicamente a estratégia de apoiar a criação de cooperativas

${ }^{25}$ É o que se pode depreender das entrevistas realizadas com dirigentes das cooperativas investigadas. 
de trabalhadores revela uma nova inflexão política do movimento sindical que pode ser caracterizada como uma estratégia defensiva por parte dos trabalhadores num contexto de reestruturação produtiva. Mas, se tal inflexão política diz respeito à ação coletiva dos trabalhadores, no tocante à racionalidade dos atores individuais predomina ainda certo pragmatismo no conjunto das posturas assumidas pelos trabalhadores em relação à sua adesão à cooperativa. Nesse sentido, uma primeira postura que se pode identificar está relacionada ao próprio ato fundador da cooperativa. Trata-se da ação mais engajada e consciente politicamente, traduzindo-se naquilo que definimos como um "compromisso político", ou seja, um comprometimento em relação à cooperativa, permeado pelo discurso sindical e pela mobilização que conduziu a sua criação. Éo discurso que propõe um nexo, uma coerência entre a ação coletiva mais geral acerca do significado da formação de um empreendimento de autogestão e as condutas individuais dos trabalhadores. ${ }^{26}$ É o que está estampado na seguinte fala:

... eu fiz parte da diretoria do sindicato por doze anos, quando deu o processo todo aqui eu era dirigente sindical. Vou dizer pra ti, hoje, nós estamos aqui hoje na cooperativa com toda garra nossa, com toda militância, aquela de fazer e acontecer, vou dizer pra ti; $100 \%$ é os Metalúrgicos de Canoas que nos deu essa oportunidade, e com a experiência que eu e mais alguns companheiros tem do movimento sindicalista, da luta do dia a dia, a gente chegou onde chegou, o sindicato [...] Tem gente que não gosta, mas eu digo que é 100\% (Presidente da cooperativa A, 48a.).

A par do compromisso político que detectamos no núcleo fundador e catalisador das cooperativas, teríamos uma segunda figura do comprometimento caracterizada pelos vínculos de solidariedade que se tornam mais consistentes quando confrontados pela adversidade. Trata-se de um discurso que afirma seu compromisso em relação à cooperativa sem estar embebido pelo discurso sindical. Não se configura num compromisso fixado a partir de um projeto político do sindicato,

${ }^{26}$ Tal postura já havia sido também detectada com mais ênfase por Rosenfield (2003). mas sim num compromisso moral afirmado a partir das sociabilidades secundárias constituídas no seio da cooperativa. Antes de operar uma separação entre duas dimensões mutuamente referidas à política e à moral, a distinção entre dois tipos de comprometimento busca apenas revelar uma nuance sutil no discurso dos trabalhadores. O segundo tipo de postura assumida em relação à cooperativa é caracterizado, como vimos anteriormente, pela crítica em relação à direção das cooperativas. Existe ainda um compromisso com o projeto da cooperativa, mas o desencanto, a discordância e as decepções marcam um discurso de protesto, de crítica. O tom de protesto pode ser conferido na seguinte fala: "Eu tô frustrado, triste, porque é uma situação triste trabalhar em uma coisa que tu gosta, numa firma pertinho de casa, que tem tudo pra dar certo e, no entanto, é mal-administrada." (Associado, 38 a. - Cooperativa B). O terceiro tipo de postura assumida em relação à cooperativa é caracterizado pelo cálculo estratégico na sua forma pura, ou seja, não são ponderados outros valores na definição do curso da ação senão a relação que se estabelece entre meios e fins. Um trabalhador ingressa na cooperativa "Porque na rua tava ruim, não tinha outro serviço." (Associado, 51 a. - Cooperativa B). Aqui, não são invocadas outras razões para justificar a permanência na cooperativa senão a mesma lógica que caracteriza o free rider. No entanto, essa postura mais pragmática é objeto de uma reiterada crítica entre os trabalhadores mais comprometidos com o projeto da cooperativa. Ao ser detectada, tal postura é rejeitada pelos próprios associados. Esse fato é patenteado por depoimentos como este: "Eles prefeririam estar trabalhando numa empresa de carteira assinada, recebendo no final do mês, serem alienados, do que terem que pensar, se preocupar, ir para casa ou ter alguma ideia..." (Membro da direção da cooperativa B, 26 a.).

\section{OS PROCESSOS DE SUBJETIVAÇÃO}

Os processos de diferenciação social que caracterizam as sociedades contemporâneas 
ensejam uma multiplicidade de modos de inserção e pertencimento social, o que termina por se refletir sobre a conformação da identidade do sujeito com descontinuidade e fragmentação de sua experiência individual. Ou seja, trata-se de uma situação na qual os atores passam a adotar vários pontos de vista, configurando sua identidade a partir de diferentes perspectivas. Nesse sentido, voltando a Dubet (1996), podemos abordar a questão identitária a partir de três registros principais: a integração social, a ação estratégica e os processos de subjetivação. No primeiro registro, a identidade pode ser percebida como uma construção social, na qual o indivíduo incorpora sua experiência vivida no curso dos processos de socialização primária e secundária, definindo quase que uma espécie de segunda natureza. Trata-se, portanto, de uma identidade que pode ser pensada como uma incorporação de um habitus, ou seja, como a absorção de um conjunto de disposições sociais oriundas não apenas da família ou da extração de classe, mas também do conjunto dos sistemas de ação com os quais o indivíduo cruzou ao longo de sua vida. No registro da ação estratégica, a identidade é construída pelos atores como um recurso, num contexto no qual a sociedade é percebida como um espaço concorrencial nos termos mesmo de um mercado ou de mercados de trabalho quando se trata da construção de identidades profissionais. $\mathrm{O}$ ator irá definir sua identidade em termos de um estatuto a partir do qual é capaz de mobilizar recursos expressos em capital simbólico ou atributos relacionados à sua posição e suscetíveis de classificá-la em relação ao conjunto das outras posições existentes em mercados de trabalho externos ou internos. Por fim, no registro da subjetivação, a identidade será entendida mais como uma possibilidade, cujo pressuposto é configurado a partir de um distanciamento crítico assumido pelo sujeito em relação à integração e à ação estratégica. Dado que o sujeito não pode ser reduzido somente à interiorização do social, tampouco à persecução de interesses, é necessário conceptualizá-lo também a partir de uma dimensão emancipatória, caracterizada pelo engajamento em modelos culturais alternativos capazes de definir novos padrões de socialização primária e secundária, bem como de individuação, contrapondo-se, dessa forma, a modelos culturais dominantes.

No âmbito das cooperativas de produção, iremos nos deparar com a construção de novas identidades a partir do momento em que o compromisso com o projeto de autogestão é afirmado. Não obstante, para alguns trabalhadores, o sentimento de ser assalariado ainda permanece. Seus vínculos de solidariedade em relação à cooperativa são predominantemente de tipo contratual e assumem uma disposição pragmática mais do que um engajamento e comprometimento em relação ao ideal de cooperativismo que embasa o projeto coletivo. Para ilustrar tal postura selecionamos a seguinte fala de um trabalhador: “... agora a sensação é como se eu tivesse trabalhando em qualquer outra empresa. É realizar um trabalho pra qualquer outra empresa que eu estivesse trabalhando, realizar um trabalho bem feito, visando resultado." (Associado, 25a. - Cooperativa A).

Contrariamente, também se pode constatar que a identidade com a antiga empresa, ou seja, a identidade de trabalhador assalariado é colocada em cheque no curso do processo de constituição das cooperativas de produção. Os trabalhadores afirmam sua identidade ao sentirem orgulho daquilo que são a partir da própria experiência das mobilizações que antecederam a criação das cooperativas. A memória afetiva desse processo de lutas contribui para forjar uma nova identidade, que não é mais a identidade de trabalhador assalariado, mas sim a identidade de um trabalhador associado a uma cooperativa de produção. São "donos" da produção e se sentem co-responsáveis em relação aos processos de trabalho e produção da cooperativa. A autoestima que decorre desse envolvimento contribui também para o reconhecimento da utilidade social desses trabalhadores, devolvendo-lhes a dignidade quase que perdida ante a situação a que foram confrontados com a perspectiva de perda do emprego. A opção, para muitos desses trabalhadores, seria a economia informal, o trabalho incerto e mal remunerado, em 
suma, a perda de controle sobre uma existência, caracterizada pelo acaso, pela contingência. A possibilidade de participar da cooperativa, regulando direitos e obrigações, também estabelece, nos termos de uma solidariedade contratual, uma espécie de “cidadania fabril”, tal como será evocada nas falas seguintes:

... como a gente costuma brincar, agora não somos empregados, somos donos. Entre aspas, porque o prédio, o chão da fábrica, nada é nosso, mas a produção é. É uma estima ver o caminhão levando embora o trabalho que tu fez. Tá entrando dinheiro. Vale a pena (Associado, 43 a. Cooperativa A)

Eu trabalhava na antiga empresa e eu tinha conhecimento do projeto que tavam fazendo da cooperativa, e através disso quando tava tudo pronto eu recebi o convite pra participar. Nos últimos tempos, a gente vinha já numa crise de identidade muito grande, porque a empresa não oferecia muita coisa pra nós e já existia esse espírito de fazer uma cooperativa, a gente tava com os salários atrasados, não tinha perspectiva nenhuma, e se unindo seria melhor (Associado, 57a. - Cooperativa B).

Aqui, no nosso caso, que não foge das outras cooperativas, a gente está sendo uma classe que sempre tentou, que o espírito mesmo da cooperativa é tu te sentir dono do teu próprio negócio. Então, aquela classe trabalhadora que existia na companhia antes, a gente se sentia aqui dentro como um trabalhador profissional. No meu caso, eu me sentia profissional na minha área. Hoje eu me sinto mais à vontade, já não levo tanto pro lado profissional, levo mais pelo lado competitivo da própria cooperativa, porque eu posso me manifestar mais, eu posso me estender mais um pouquinho pra citar uma ideia, desenvolver minha própria ideia. A gente ficou mais cidadão aqui dentro, porque tu tem mais liberdade de expressão, mais liberdade de atingir um objetivo e tu conseguir pelo menos metade, coisa que antes não ocorria. Ficou mais aberto pro lado cidadão. Acho que o termo cidadão seria o termo certo, que é o que todos fazem, ficar mais à vontade (Associado, 49a. - Cooperativa B)

Os processos de deliberação democrática através das assembleias também contribuem para o senso de co-responsabilidade, para ressaltar que o êxito do empreendimento de autogestão está atrelado ao compromisso dos trabalhadores em relação à cooperativa. Essa questão, que pode parecer evidente à primeira vista, encerra, no entanto, 0 principal desafio da empreitada autogestionária: estando calcados em princípios que gravitam em torno das noções de autonomia e cooperação, tais empreendimentos têm sido objeto de abordagens que enaltecem a democracia, sem, entretanto, qualificar suas condições de possibilidade.

Familiarizados com relações sociais marcadamente hierárquicas em toda sua história laboral, seus costumes, disposições e atitudes não se coadunam facilmente com a isonomia. Com efeito, a experiência da democracia em um espaço fabril, notabilizado tradicionalmente por um regime de interação hierárquico, deve ser reatualizada reiteradamente, dado que, para alguns trabalhadores o espectro das antigas sociabilidades ainda permanece: “... tem gente ainda aqui dentro da fábrica que ainda acha que é empregado e que acha que o presidente da cooperativa é o dono da cooperativa, isso também tem aqui dentro." (Presidente da Cooperativa B, 29a.). Assim, embora o princípio da igualdade também seja percebido e valorizado pela maioria dos trabalhadores associados às cooperativas, o mesmo não se traduz numa participação mais intensa e equilibrada nas assembleias, ou seja, numa sociabilidade mais horizontal entre os trabalhadores das cooperativas. O que remete, de resto, para um importante obstáculo à configuração de cooperativas plasmadas pela participação igualitária de seus associados e que está relacionado à constituição de um repertório atitudinal assentado em novas formas de crer e agir no âmbito da experiência do trabalho associado que não se produzem de um dia para o outro.

\section{CONSIDERAÇÕES FINAIS}

No contexto constituído pelas cooperativas de produção, caracterizado pela autogestão e por processos decisórios que pressupõem a participação de todos os associados, a principal demanda em termos das relações sociais tramadas no seu interior será pelo reconhecimento aos direitos e obrigações de cada um, definidos no regimento interno. Ressalte-se que não se trata aqui somente de vínculos de solidariedade funcional e contratual, 
cujo sentido se resume na coalescência das relações sociais nas cooperativas de produção, mas de perceber também as relações de solidariedade como um modo de reconhecimento recíproco entre os associados às cooperativas, a partir de um conjunto de valores compartilhados, tendo em vista à persecução de objetivos comuns. As relações de reconhecimento aqui consideradas se traduzem, sobretudo, em consideração e estima social recíprocas por parte dos trabalhadores que pertencem a cada cooperativa, a partir mesmo das características e atributos pessoais que os diferenciam. Logo, não estamos tratando de um reconhecimento assentado somente em princípios abstratos e universais, mas num tipo de reconhecimento que surge das relações de solidariedade, privilegiando, desse modo, a eticidade concreta de determinados grupos sociais. Nesse aspecto, existe uma equação entre estima social e o princípio igualitário, que pode ser disposta da seguinte forma: quanto mais a eticidade concreta do grupo social estiver descentrada e quanto mais prevalecer uma sociabilidade horizontal, em detrimento de possíveis ordenações hierárquicas, tanto mais a estima e consideração social assumirão um formato individualizante, dando vez, desse modo, a relações de natureza simétrica (Honneth, 1992).

Dessa forma, podemos identificar, nas duas cooperativas pesquisadas, o empenho para uma transição, não sem solavancos, de um regime de interação hierárquico para um regime de interação igualitário, a partir mesmo da forte crítica dos trabalhadores às relações de mando que caracterizavam as empresas a partir das quais as cooperativas foram criadas. ${ }^{27}$ As hierarquias formais que prevalecem dizem antes respeito à própria divisão de tarefas existente. A mudança nas relações de poder a partir da instituição de uma nova forma de regulação, de um novo ordenamento das relações entre os trabalhadores a partir do primado da ideia de direitos iguais, concorre para afirmar a solidariedade entre os membros das cooperativas, pois as decisões em relação ao trabalho devem ser negoci-

${ }^{27}$ Para a noção de regime de interação, ver Goffman (1983) e Martuccelli (2002). adas entre aqueles que pertencem ao grupo. Não obstante, se os trabalhadores passam a ter mais autonomia em relação aos processos de trabalho e produção, a heteronomia do mercado segue sendo a coerção que define os limites de seu campo de possíveis. Mas traços das antigas hierarquias que conformavam uma identidade pessoal submissa e subserviente ainda se manifestam nas práticas de alguns trabalhadores, que percebem, nos membros da direção das cooperativas, a imagem de novos patrões. Habituados a um tipo de gestão paternalista, característica da condução familiar das antigas empresas há pelo menos três gerações, alguns trabalhadores ainda relacionam sua inserção e pertencimento social à proteção daquele que manda.

As particularidades dos processos de trabalho que caracterizam as duas cooperativas estabelecem diferenciações no tocante à nova estrutura de cargos e salários instituída após a criação de cada cooperativa. Uma das cooperativas produz bens de capital sob encomenda, o que demanda uma força de trabalho especializada num ofício artesanal com qualificações tácitas e formais adquiridas ao longo de uma carreira profissional. Na outra cooperativa, o processo de trabalho é organizado com vistas à fabricação de bens de consumo em série, com níveis de qualificação bem distintos ao longo de todas as fases do processo produtivo. Nesses termos, a estrutura de cargos e salários de cada cooperativa busca contemplar tais especificidades. Assim, a definição do plano de cargos e salários busca estabelecer uma mediação entre a antiga estrutura e a conformação de uma nova, na qual a tendência à equalização dos salários se inscreve no horizonte futuro de cada cooperativa. Nesse aspecto, os trabalhadores acenam para uma possível mudança no futuro. Entretanto, para alguns trabalhadores, mesmo a estrutura de cargos e salários definida após a criação de cada cooperativa é motivo para crítica e protesto. $\mathrm{O}$ acento de tal postura crítica é dado em favor da proposição de uma estrutura mais igualitária, a partir da redução dos próprios níveis salariais que terminam concorrendo para a reprodução de uma estrutura hierárquica criticada pelos trabalhadores 
entrevistados. Entretanto, as críticas em relação à persistência de hierarquias derivadas das diferenciações salariais só podem surgir num contexto onde os trabalhadores podem protestar sem o receio de retaliações. Ao mesmo tempo, embora o princípio da igualdade também seja percebido e valorizado pela maioria dos associados, ele ainda não se traduz numa participação mais intensa e equilibrada nas assembleias, ou seja, numa sociabilidade mais horizontal entre os trabalhadores das cooperativas. É possível que esse déficit de participação seja o resquício e a ressonância de uma cultura política autoritária e paternalista que ainda tolhe as perspectivas da mudança subjacentes às práticas dos trabalhadores de cada cooperativa. $\mathrm{O}$ que, de resto, também contribui para definir o alcance da inovação social representado por essas experiências de autogestão.

(Recebido para publicação em 07 de março de 2010) (Aceito em 04 de abril de 2011)

\section{REFERÊNCIAS}

AGLIETTA, Michel. Regulación y crisis del capitalismo. La experiencia de los Estados Unidos. México: Siglo XXI, 1979.

BAJOIT, Guy. Pour une sociologie relationnelle. Paris: PUF, 1992.

CARDOSO, Adalberto Moreira. Sindicatos, trabalhadores e a coqueluche neoliberal: a era Vargas acabou? Rio de Janeiro: Editora FGV, 1999.

CASTEL, Robert. As metamorfoses da questão social: uma crônica do salário. Petrópolis: Vozes, 1998.

CEFAÏ, Daniel. Pourquoi se mobilise-t-on? Les théories de l'action collective. Paris: La Découverte, 2007.

; MARTUCCELLI, Danilo. ¿En qué sociedad vivimos? Buenos Aires: Editorial Losada, 1999.

GOFFMAN, Erving . El orden de interacción. In: WINKIN, Yves (Org.) Los momentos y sus hombres. Barcelona: Páidos, 1991.

GOHN, Maria da Glória. Teoria dos movimentos sociais: paradigmas clássicos e contemporâneos. São Paulo: Edições Loyola, 1997.

GORZ, André. Metamorfoses do trabalho: crítica da razão econômica. São Paulo: Annablume, 2003.

Misérias do presente, riqueza do possível. São Paulo: Annablume, 2004.

HABERMAS, Jürgen. Teoría de la acción comunicativa: racionalidad de la acción y racionalización social.. Madrid: Taurus Ediciones, 1987. v.1

Consciência moral e agir comunicativo. Rio de Janeiro: Tempo Brasileiro, 1989.

HIRSCHMAN, Albert. Saída, voz e lealdade. São Paulo: Perspectiva, 1973.

HONNETH, Axel. La lutte pour la reconnaissance. Paris: Les Éditions du Cerf, 2002.

HUMPHREY, John. O impacto das técnicas “japonesas" de administracão na indústria brasileira. Novos Estudos CEBRAP, São Paulo, n.38, p.148-167, mar., 1994.

HYMAN, Richard. Los Sindicatos y la desarticulación de la clase obrera. Revista Latinoamericana de Estudios del Trabajo, México, D.F., ALAST, n.4, p.9-28, 1996.

LAPOINTE, Paul-André. Identités ouvrières et syndicales, fusion, distanciation et recomposition. Sociologie et Sociétés, Montréal, v.30, n.2, p.1-24, automne, 1998.

LÉVESQUE, Christian; MURRAY, Gregor ; LEQUEUX, Stéphane. Transformations sociales et identités syndicales: l'institution syndicale à l'épreuve de la différenciation sociale contemporaine. Sociologie et Sociétés, Montréal,v.30, n.2, p.1-24, automne, 1998.

LIMA, Jacob C. Cooperativas de produção industrial: autonomia e subordinação do trabalho. In: CASTRO, Nadya A.; DEDECCA, Claudio S. (Org.) A ocupação na AméricaLatina: tempos mais duros. São Paulo; Rio de Janeiro: ALAST, 1998

O trabalho autogestionário em cooperativas de produção: o paradigma revisitado. Revista Brasileira de Ciências Sociais, São Paulo, ANPOCS, v.19, n.56, p.4562 , out., 2004

LUKÁCS, Georg. História e consciência de classe. Porto: Publicações Escorpião, 1974.

MAGALHÃES, Reginaldo Sales; TODESCHINI, Remígio. Sindicalismo e economia solidária: reflexões sobre o projeto da CUT. In: SINGER, Paul; SOUZA, André R. A economia solidária no Brasil: a autogestão como resposta ao desemprego. São Paulo: Contexto, 2000.

MARTUCCELLI, Danilo. Grammaires de l'individu. Paris: Gallimard, 2002

POCHMANN, Márcio. O emprego na globalização: a nova divisão internacional do trabalho e os caminhos que o Brasil escolheu. São Paulo: Boitempo, 2001

RAMALHO, José Ricardo. Trabalho e sindicato: posições em debate na sociologia hoje. DADOS: revista de Ciências Sociais, Rio de Janeiro, IUPERJ, v.43, n.4, 2000.

REYNAUD, Jean-Daniel. Les règles du jeu. L'action collective et la régulation sociale. Paris: Armand Colin, 1997.

RODRIGUES, Leôncio Martins. Destino do sindicalismo. São Paulo: Edusp, 1999.

ROSENFIELD, Cinara L. A autogestão e a nova questão social: repensando a relação indivíduo-sociedade. Civitas, Porto Alegre, v. 3, nº2, p. 395-415, 2003.

SAHLINS, Marshall. Economía de la edad de piedra. Madrid: Akal Editor, 1977. 
SANTOS, Boaventura de S.; RODRÍGUEZ, César. Para ampliar o cânone da produção. In: SANTOS, Boaventura de S. (Org.) Produzir para viver: os caminhos da produção não capitalista. Rio de Janeiro: Civilização Brasileira, 2002.

THOMPSON, Edward P. A formação da classe operária inglesa: a árvore da liberdade. Rio de Janeiro: Paz e Terra, 1987. v.1

TOURAINE, Alain. Production de la société. Paris: Seuil, 1973.
Pour la sociologie. Paris: Seuil, 1974.

VALLE, Rogério. Autogestão: o que fazer quando as fábricas fecham? Rio de Janeiro: Relume-Dumará, 2002.

WALZER, Michael. As esferas da justiça: em defesa do pluralismo e da igualdade. Lisboa: Editorial Presença, 1999 WEBER, Max. Economía y sociedad. México DF.: FCE, 1990 


\section{THE GRAMMAR OF ACTION OF WORKERS IN PRODUCTION CO-OPERATIVE IN SOUTH OF BRAZIL}

\author{
Ricardo Mayer
}

This paper seeks investigating the grammar of action of workers in production co-operative established in the core of the processes of economical restructuring that took place in Brazil in the 1990s. Based upon a sociology of experiment, we split up logic of actions from the workers engaged in the formation of two production co-operative where we aimed to investigate: a) the solidarity relationships, b) logic of the strategic actions in each work group, c) the subjective processes expressed in the identity construction workers of the co-operative investigated. Investigating two production co-operative in the metropolitan area of Porto Alegre, it was verified a process of subjectivity marked by an ambivalent attitude between the commitment to the project of building the co-operative and an approach guided by certain pragmatic characterised by a field of possibilities, limited regarded to alternative of social reintegration.

KEY WORDS: grammar of action, solidarity, production co-operative, self-management, sociology of experiment.

\section{LA GRAMMAIRE DE L'ACTION DES TRAVAILLEURS DANS DES COOPÉRATIVES DE PRODUCTION DU SUD DU BRÉSIL}

\author{
Ricardo Mayer
}

Il s'agit d'une recherche sur la grammaire de l'action des travailleurs organisés en coopératives de production, créées dans le cadre du processus de restructuration économique qui a eu lieu au XXe siècle, au Brésil, à partir des années 90. En nous basant sur une sociologie de l'expérience, nous avons décomposé la logique de l'action des travailleurs engagés dans la formation de deux coopératives de production. Nous avons donc analysé: a) les liens de solidarité, b) la logique de l'action stratégique dans tous les groupes de travailleurs, c) les processus de subjectivation exprimés dans la construction identitaire des travailleurs des coopératives étudiées. L'investigation faite dans deux coopératives de production de la région métropolitaine de Porto Alegre, limitée aux alternatives de réinsertion sociale, a permis de vérifier un processus de subjectivation marqué par une attitude ambivalente entre l'engagement envers le projet de construction de la coopérative et une attitude pragmatique déterminée par un champ de possibles.

MOTS-CLES: grammaire de l'action, solidariété, coopératives de production, autogestion, sociologie de l'expérience.

Ricardo Mayer - Doutor em Sociologia. Professor do Programa de Pós-Graduação do Centro de Ciências Sociais e Humanas da Universidade Federal de Santa Maria - UFSM. Editor da Século XXI - Revista de Ciências Sociais. Membro do Conselho Editorial da Latitude - Revista do Programa de Pós-Graduação em Sociologia do ICS/UFAL. Tem experiência na área de Sociologia, com ênfase em Teoria Sociológica, Sociologia Política e Sociologia do Trabalho, concentrando-se principalmente nos seguintes temas: desigualdade, reconhecimento, identidade, alteridade e ação coletiva. Publicações recentes: Sociologia da experiência e lutas por reconhecimento: associações de geração de trabalho e renda no sul do Brasil. Sociologia (Lisboa), v. n. 61, p. 65-84, 2009; A lógica do respeito: notas críticas em torno do conceito de reconhecimento. Latitude (UFAL), v. 2, p. 34-67, 2008. 